\title{
Unpacking 'the Imaginary Texture of the Real' with Kant, Sartre and Merleau-Ponty
}

\author{
By KATHLEEN LENNON \\ University of Hull
}

\begin{abstract}
In this paper I put forward a concept of the imagination which weaves together many of the key and overlapping dichotomies around which discussions of the imagination have circled: dichotomies between the productive and reproductive, between presence and absence, between creativity or spontaneity and receptivity or passivity, between invention and disclosure, between cognition and affect. Inter-implicated with these dichotomies is that between imagination and perception. Utilising the work of Kant and Merleau-Ponty, and in critical conversation with Sartre, I distil an account of the imagination which cuts across these dichotomies, delineating a capacity which is at work in perception, as well as in the range of activities of "phantasing" or "conjuring up", to which the term is often restricted.
\end{abstract}

\section{Imagination and Image}

Central to the account of the imagination which I wish to defend in this paper is a recognition of the imagination working within everyday experience. Imagination is, I shall suggest, a (creative) capacity to experience the world in a certain way, in the form of images. The concept of image here is much wider than what is sometimes taken to be its standard definition: "the internal [or external] representation of a sensory object in the absence of a corresponding sensory stimulus"1. What marks each of the writers that I will discuss here is the rejection of such a conception of images (deriving from

\footnotetext{
${ }^{1}$ Brann E. T. H., 1991, The World of the Imagination, Rowman \& Littlefield, p. 13.
} 
the writings of Hume), as faint copies of sensory perceptions in an inner mental realm of the imagination. As Merleau-Ponty points out:

The word image is in bad repute because we have thoughtlessly believed that the design was a tracing, a copy, a second thing and that the mental image was ... belonging among our private bric a brac. But in fact it is nothing of the kind ... They are [that] ... without which we would never understand the quasi presence and imminent visibility which make up the whole problem of the imaginary ${ }^{1}$.

In place of an account of images as copies lined up in an inner faculty, here they are viewed as the shapes or forms in terms of which we experience the world, which weave together the present and absent, in a way that requires both invention and discovery, and remains open to possibilities of revision. To speak of images in this way, and of the imagination as that which concerns such images, is not to employ a usage quite removed from our everyday one. When we speak of people as imaginative, we do not usually mean that they live in a world of make believe, played out within their interior life. We often mean that they are particularly perceptive, sensitive to the shapes which the world (including others) around them, can take. On this wider conception of the imagination the activities of conjuring up or fantasising is just one arena in which the imagination is at work. (Though, even here, it is questionable whether the Humean picture is the correct one). Imagination is therefore at work, in Strawson's words, in

seeing a cloud as a camel or a ... formation of stalagmites as a dragon ... in the first application of the word 'astringent' to a remark ... to a ... scientist seeing a pattern in phenomena which has never been seen before ... to Blake seeing eternity in a grain of sand and heaven in a wild flower ${ }^{2}$.

\section{Kant: The Imagination and the Art of Synthesis}

The articulation of such an account begins with Kant. The productive imagination was an active faculty, for Kant, central to the synthesis which was necessary for us to have perceptual experiences at all. For Kant our

\footnotetext{
${ }^{1}$ Merleau-Ponty M., 1993, "Eye and Mind" in Galen A. Johnson (ed.), The MerleauPonty Aesthetics Reader, Northwestern University Press, Evanston, Illinois, p. 126.

2 Strawson P., 1974, "Imagination and Perception", in P. Strawson, Freedom and Resentment, Methuen, London, p. 95.
} 
perceptual experience is never an awareness of momentary, brute sensory data. It is always an awareness of, what he terms, a manifold of intuitions, always and already organised/shaped. This shaping of a manifold is what Kant refers to as synthesis. The activity of synthesis is the distinctive activity of the productive imagination ${ }^{1}$.

What is first given to us is appearance. When combined with consciousness it is called perception ... Now, since every appearance contains a manifold, and since different perceptions therefore occur in the mind separately and singly, combination of them such as they cannot have in sense, is demanded. There therefore must exist in us an active faculty for the synthesis of this manifold. To this faculty I give the name imagination ... imagination has to bring the manifold of intuition into the form of an image ${ }^{2}$.

Here Kant is using the concept of image in a broad sense and not just to denote visual images. Images are the shape or form given to a sensory manifold by the imagination.

The Kantian account which stresses that in perceptual experience we have synthesised sensory data, is important in drawing our attention to the "seeing as" structure of perception, which is one stressed by a multitude of writers. Strawson illuminatingly compares the Kantian discussion with Wittgenstein' s. In the Kantian account, the imagination is at work, not only when a child treats a broom as a horse, but when she perceives a horse as a horse also ${ }^{3}$. In each case a multiplicity of sensations is organised into a shape or form which enables us to experience it as something. In Michael Young's terms our perceptual experience involves a "construing as", and such construal requires the imagination ${ }^{4}$. For Kant perception requires synthesis and synthesis requires the workings of both the productive and the reproductive imagination. The apprehension of a manifold requires that a multiplicity of intuitions "must be run through and held together", so that the momentary present can be linked to what is not immediately presented to us. The

\footnotetext{
${ }^{1}$ Kant I., 1929 [1781/1787], Critique of Pure Reason, A120, transl. N. Kemp Smith, London, McMillan, p. 144.

${ }^{2}$ Ibid.

${ }^{3}$ Guyer Paul, 2004, "Kant Immanuel (1724-1804)", Routledge Encyclopedia of Philosophy online.

${ }^{4}$ Young J. M., 1988, “Kant's View of Imagination”, Kant Studien, vol. 79, p. 140164.

${ }^{5}$ Kant I., 1929 [1781/1787], Critique of Pure Reason, A120, transl. N. Kemp Smith, London, McMillan, p. 183.
} 
capacity, the making of the absent present, is what, in Fiona Hughes words ${ }^{1}$, "makes possible our transcendence of the mere moment or present and "sets us in relation to something other than ourselves". The reproductive imagination keeps absent experiences in play and the productive imagination unites this manifold of the present and absent into a unity, a synthesised image. The reproduction involved here is, I think, best understood through Strawson's discussion. He discusses what is involved in perceiving a dog. "To perceive something as a dog, when silent and stationary, is to see it as a possible

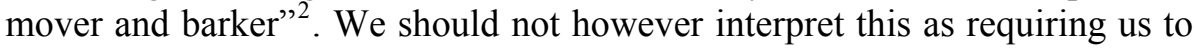
conjure up inner mental images of the dog moving or barking. Most of the time, we do not do that. Rather, the possible moving and barking is alive in the immediate and present perception of the dog. We will return to this below, for it is pivotal to Merleau-Ponty's discussion. But it is important to note in the context of contemporary discussions of perception in which the phenomena of the 'absent present' is often accommodated by the postulation of additional unconscious mental images.

In the section of the First Critique entitled the Schematism, Kant describes the workings of the imagination "an art concealed in the depths of human soul, whose real mode of activity nature is hardly likely ever to allow us to discover" ${ }^{3}$. This art is the art of being able to detect in the manifold a possibility or possibilities of unification. It requires both activity and passivity, (spontaneity and receptivity); receptivity to intuitions and spontaneity in grasping the possibilities for synthesis. But the resulting phenomenal experience is not one in which these different components can be disentangled. In Kant's account of the productive imagination, in the Critique of Pure Reason, the way the synthesis is produced, and the consequent form which the world takes for us, is constrained by the categories, universal rules to which all perceptual content must conform. Consequently there is a question mark over how much room the imagination has for the exercise of creativity. Moreover in that text Kant is primarily concerned with cognitive synthesis. However, in Kant's account of beauty in the Critique of Judge$m e n t^{4}$, we have an account of the productive imagination operating without the application of determining rules and an interweaving of image and affect.

${ }^{1}$ Hughes F., 2007, Kant's Aesthetic Epistemology, Edinburgh University Press, Edinburgh, p. 147.

${ }^{2}$ Strawson P, "Imagination and Perception", art. cit., p. 89.

${ }^{3}$ Ibid.

4 Kant I., 2007 [1790], Critique of Judgement, trans. J.C. Meredith, Oxford University Press, Oxford. 
In this text Kant returns to the question of the possibility of judgment, which had formed a focus of the Schematism. Judgment in general, for him, is the faculty for thinking the universal within the particular. In his previous discussion he had viewed this process as a process of subsumption. The particular instance is brought under a concept, which we hold prior to our encounter with the concrete. In this process the concepts provide the rules for the imagination, guiding the process of synthesis. In this later work, however, he pays attention to a different category of judgement, what he terms reflective judgement. In such judgments the imagination is searching for a form. It is within this context that he gives his account of the appreciation of beauty. Judgements of taste are not cognitive judgements. Perception of beautiful objects, Kant recognises, are connected to feelings of pleasure. Feelings for him are subjective and non cognitive. Nonetheless such subjective feelings are the ground of aesthetic judgments of beauty which appear to make claims of universal validity. How can this be so? Well, for him, the feeling of pleasure is the experiencing of the harmonious relation between the manifold of sense and our understanding. Such a feeling is different from that of both pleasurable sensations and the esteem we feel for the morally good. It has a quality of disinterestedness linked to the recognition of its potential validity for others.

The harmony here is due to the work of the imagination, exercising its freedom in detecting, in what is presented, something which is intelligible to us. Fiona Hughes describes this in the following way: "the beautiful marks a moment when the ... [imagination] makes sense of something in the world"1. The beautiful thing is one in which the imagination can creatively weave a form that displays "the harmonious interplay of understanding and imagination"2 (Kant stresses here that the source of the beauty is form; colour, taste, smell, texture are excluded. But we do not need to follow him in this). Although the feeling of pleasure which constitutes the detection of such harmony is subjective, it makes demands of a universal kind. For, if the imagination has done its job properly, and given Kant's humanist assumption that the facilities of human sensibility and understanding are universally shared, then when this form is made evident to others, they should also experience the same feeling. This is not just a claim about a causal regularity: the same objects causing the same feelings because we are made the same

\footnotetext{
${ }^{1}$ Hughes F., 1997, Kant's Aesthetic Epistemology, op. cit., p. 6.

${ }^{2}$ Schaper E., 1992, "Taste, sublimity and genius: The aesthetics of nature and art", in P. Guyer (ed.), The Cambridge Companion to Kant, Cambridge University Press, Cambridge, p. 373.
} 
way, as some writers ${ }^{1}$ seem to suggest. Once the harmony has been made manifest, then everyone would be justified in sharing the feeling, and indeed should do so. Failure to have the feelings is failure to detect the harmony. As Kant remarks "the assertion is not that everyone will fall in with our judgement, but rather that everyone ought to agree with it"2.

Whatever we may think about this as an account of aesthetic beauty, Kant has given us a model, of the way in which the imagination can work, creatively (and without concepts), which can have a more general application. It is one in which the activity of synthesis is put together, as MerleauPonty later stresses, with a receptivity, in a giving over of the subject to the world; but also of an accountability to that world, delivered by the necessity of others recognising the appropriateness of the images/forms, which we imaginatively both create and detect. It is also a model in which the workings of the imagination is tied to affect. The images produced are affective and not simply cognitive. "A given object, through the intervention of sense, sets the imagination at work in arranging the manifold, and the imagination" The productive imagination in this later work of Kant, allows a creative apprehension of the form of the sensible. He argues here that we employ our creative imagination in seeking a form in the sensible world, whose validity depends on it being recognisable (and felt) by others. The form which we apprehend in the sensory manifold must be a possible form for the world to take. Such a dimension of creativity, if attached to an account of perception in general, allows for the possibility of our world being imagined in different ways, formed into a variety of images; "interminable reinterpretations to which it is legitimately susceptible" ${ }^{4}$.

Many read Kant's account as impositionist ${ }^{5}$. According to this model the imagination simply imposes forms on an indeterminate given, in accordance with rules derived from the understanding. But this does not seem right. His account requires that the world encountered is one which is apt for the forms which we both seek out and impose upon it. In his discussion of synthesis Kant stresses that the manifold which is encountered must be one which is synthesisable. And in the Critique of Judgement the a

\footnotetext{
${ }^{1}$ Cohen T., and Guyer P., 1982, Essays in Kant's Aesthetics, University of Chicago Press, Chicago, Introduction.

${ }^{2}$ Kant I., 2007 [1790], Critique of Judgement, op. cit., p. 85.

${ }^{3}$ Ibid., p. 83.

4 Merleau-Ponty M., 1993, "Eye and Mind", in Galen A. Johnson (ed.), The Merleau-Ponty Aesthetics Reader, Northwestern University Press, Evanston, Illinois, p. 139.

${ }^{5}$ Hughes F., 1997, Kant's Aesthetic Epistemology ${ }_{2}$ op. cit.
} 
priori principle which renders judgement possible, is that nature is susceptible to our faculties "a principle without which understanding could not feel itself at home in nature" . Nature must be susceptible to such images for them to be projectibly detectable by ourselves and others. This is also a feature of his account which is picked up and developed by Merleau-Ponty.

What, however, haunts Kant's account of the imagination and makes it problematic for many, amongst whom I count myself, is that it seems to offer a picture of a noumenal subject confronting a noumenal world. The imagination can then appear as a faculty of just such a noumenal subject. (A quite contrary danger, which Kant himself seemed to be aware of in rewriting for the second edition of The Critique of Pure Reason, is that the description of the three moments of synthesis found in the first edition, are read as a characterisation of an empirical process of sensory processing of empirical subjects). In the work of Merleau-Ponty we find an account which rejects a noumenal subject, while retaining the fundamental Kantian insight that the imagination is what yields the texture of the real.

\section{Sartre and Merleau-Ponty: Absence and Presence}

Before turning to Merleau-Ponty, however, we need to address Sartre's writings on the Imaginary, with which Merleau-Ponty was in conversation. One of the great strengths of Sartre's account is the way in which he sees the imaginary at work across a range of situations, in the way in which we can see doodles as animals, clouds as castles, take a photograph or a portrait to be a portrait of someone or something; or produce and engage with art works in general: "mental images, caricatures, photos are so many species of the same genus" ${ }^{2}$. A genus which includes seeing "the fat and painted cheeks, black hair and female body" of the impersonator Franconay, as Maurice Chevalier ${ }^{3}$ (Here there are parallels with Peter Strawson. However in Sartre's work, in contrast to Strawson, we find a bifurcation of imagination and perception and correspondingly a bifurcation of the imaginary and the real. So although the imagination is at work when we see Franconay as Chevalier it is not at work, according to him, when we see her as Franconay.

\footnotetext{
${ }^{1}$ Kant I., 2007 [1790], Critique of Judgement, op. cit., p. 35.

2 Sartre J.P., 2004, The Imaginary, A Phenomenological Psychology of the Imagination, trans. J. Webber, Routledge, London, p. 19.

${ }^{3}$ Ibid., p. $25 \mathrm{ff}$.
} 
In his work on the imagination ${ }^{1}$ Sartre follows Husserl ${ }^{2}$ both in rejecting the empiricist account of the imagination, in which it consists in inner pale copies of perceptions, but also in insisting that imagining was a kind of intentional act distinct from perceiving. Consequently he provides an account of the imagination which also stands in contrast to Kant, for whom both the productive and the reproductive imagination were engaged in perception, in the conjuring up of mental images, and in the production of and engagement with, works of art. For Sartre in both perceiving Pierre and imagining him I am engaged in intentional acts directed in some way at Pierre. But they are intentional acts of quite different kinds: "consciousness is related [to Pierre] in two different ways" . Nonetheless "the imagining consciousness that I have of Pierre is not a consciousness of an image of Pierre" ${ }^{4}$. In perception, something is present to us, something which is in excess of any aspects we may grasp of it, and to which we can return for further information. In contrast if I imagine Pierre, then Pierre is absent, and any characteristics of this imagined Pierre are ones which I have bestowed. "A perceptual consciousness appears to itself as passive ... an imaging consciousness ... [has] a spontaneity that produces and conserves the object as imaged" $[\mathrm{my}$ emphasis]. For Sartre the act of consciousness involved in imagining is $a$ negation of the real and the constitution of an irreal image, whose distinctive mark was its absence. "In this sense one can say that the image has wrapped within it a certain nothingness ... it gives its object as not being"6

When I make of a doodle the face of a creature, what is perceived is a set of material marks. But I surpass such perception by imagining in those marks the face. Here I have gone beyond what is present to create an image which is not present. In so doing I use the material of the ink marks as the grounding of my image, but the image itself is something constituted by my acts and, for Sartre, works by negating its ground and replacing it with an image whose constitutive character is its irreality. When Sartre discusses the performance artist Franconay, we see "a small stout brunette woman" but negate this materiality to posit an image of the absent Maurice Chevalier. For

\footnotetext{
${ }^{1}$ Sartre J.P., 2012, Imagination, transl. K. Williford and D. Rudrauf, New York, Routledge; and The Imaginary, op. cit.

${ }^{2}$ Husserl E., 1970, Logical Investigations vol 2 bk 6, trans J. Findlay, New York, Humanities Press; 1962, Ideas; General Introduction to Pure Phenomenology, trans. W. Gibson, Collier, New York.

${ }^{3}$ Sartre J.P., 2004, The Imaginary, op. cit., p. 7.

${ }^{4}$ Ibidem

${ }_{6}^{5}$ Ibid., p. 14.

${ }^{6}$ Ibidem
} 
that to happen "that black hair we did not see as black; that body we did not perceive as a female body, we did not see those prominent curves"1. The absent Chevalier comes, Sartre suggests, to possess the body in front of us. (It is hard to fault the phenomenology here). Nonetheless, for Sartre, I am aware that I am spontaneously and at each moment creating this image "the image represents a certain type of consciousness, absolutely independent of the perceptual type and, correlatively a sui generis type of existence for its objects" 2 . (This seems less accurate, and to omit the phenomenological overlaps between seeing Franconay as Franconnay and seeing her as Chevalier). In each of the cases of imaginary acts which Sartre discusses there is something perceived which serves as what Sartre calls the analogon of the image which is created; the perceptual ground which we negate and surpass in the creation of the image. This model he applies to photographs, portraits and other works of art. Perception is, on this account, the passive reception of a positivity. It offers us the real. In contrast, the act of imagining requires a negation of such positivity, and the creation of an image. Imagination is therefore the realm of activity/spontaneity. Sartre rests the possibility of our freedom on such a distinction: "it is because we are transcendentally free that we can imagine" ${ }^{3}$ and we need to be able to imagine to possess such freedom. At any point we can negate the real and surpass it into an imagined future which we ourselves posit.

But Merleau-Ponty rejects the dichotomy, found in Sartre's account, for failing to accurately characterise and make sense of the phenomenology of both perception and agency. By means of a critical engagement with Kant, Merleau-Ponty offers an account of perception that incorporates elements of both receptivity and spontaneity. Nonetheless, despite their fundamental differences, what is striking in reading the two authors is the similarity to be found in their phenomenological descriptions of perceptual experience. This is particularly the case in the use of the metaphor of pregnancy. This is used first by Sartre and becomes pivotal to Merleau-Ponty. Perceptual experience is pregnant, with a past, an elsewhere, and with possibilities for our future, in a way that is captured by both writers, but which sits in tension, with Sartre's ontological dichotomy of the imaginary and the real. In his later works ${ }^{4}$ Merleau-Ponty introduces the terms visible and invisible, as terms which

\footnotetext{
${ }^{1}$ Ibid., p. 27.

${ }^{2}$ Ibid., p. 93.

${ }^{3}$ Ibid., p. 186.

${ }^{4}$ Merleau-Ponty M., 1968, The Visible and the Invisible, ed, C. Lefort, trans. A. Lingis, Northwestern University Press, Evanston.
} 
echo and replace Sartre's sets of distinctions, between the present and the absent, being and nothing, the perceived and the imagined. Throughout this later work there is an ongoing challenge to the account of our perceptual encounters which Sartre offered. Sartre's account he says "assumes ... a bipartite analysis: perception as observation, a close-woven fabric, without any gaps ... the imaginary as locus of the ... negation" ${ }^{1}$. Sartre, he complains, offers us a perceived world without depth. This he rejects. Instead "There is no thing fully observable, no inspection of the thing that would be without gaps and that would be total ... conversely, the imaginary is not an absolute unobservable. This distinction ... is not that between the full and the void" . In place of Sartre's picture he offers an account of perception in which the visible, what we might initially characterise as the perceptually present, is woven though with the invisible, the absent, present, "a visible is not a chunk of absolutely hard, indivisible being, offered all naked to ... vision ... but ever gaping open" ${ }^{3}$. He wishes to replace Sartre's account of the imaginary with "an operative imaginary ... which is indispensible for the definition of Being itself" ${ }^{\prime 4}$. This imaginary is not the freely postulated irreality which Sartre suggests but the latent depth in the perceived world. Pregnancy is again the recurrent metaphor. The visible is pregnant with the invisible. The invisible is not the non visible. It is made manifest through the visible, giving it "immense latent content of the past, the future and the elsewhere, which it announces and which it conceals" ". In Sartre's account we posit the imaginary and fix its content, but Merleau-Ponty suggests, in contrast, that "the invisible is a hollow in the visible, a fold in passivity, not pure production" " [my emphasis]. What he is offering us, therefore, is an account of "the visible as in-visible" (in the visible), in place of a binary opposition between the perceptual and the imaginary; being and nothingness.

The proper essence [le propre] of the visible is to have a layer [doublure] of invisibility ... which it makes present as a certain absence ${ }^{8}$.

\footnotetext{
${ }^{1}$ Merleau-Ponty M., 1968, The Visible and the Invisible, op. cit., p. 266.

${ }^{2}$ Ibid., p. 77.

${ }^{3}$ Ibid., p. 132.

${ }^{4}$ Ibid., p. 85.

${ }^{5}$ Ibid., p. 114

${ }^{6}$ Ibid., p. 235.

${ }^{7}$ Ibid., p. 242.

${ }^{8}$ Merleau-Ponty M., 1993, "Eye and Mind" in Galen A. Johnson (ed.), The MerleauPonty Aesthetics Reader, Northwestern University Press, Evanston, Illinois, p. 147.
} 
The visible is not the contradictory of the visible, the visible itself has an invisible inner framework ... and the in-visible is the secret counterpart of the visible, it appears only within it ... it is in the line of the visible ... it is inscribed within it (in filigree) ${ }^{1}$.

The shape of the world is an interweaving of the visible and the invisible. The framework of the visible and the invisible which Merleau-Ponty offers proves to be a rich resource for articulating multiple features of our perceptual experience. In the Phenomenology of Perception he pointed out that to recognise an object as red requires an awareness of other actual and possible reds; but it is not to conjure up these other reds. For Merleau-Ponty, the imaginary, (the invisible), is explicitly separated from the domain of representation. There is no question of memories of past experiences or anticipations of future ones being lined up in the inner realm of consciousness alongside present sensory data. Rather, for him, the other possible reds are alive in the red which we see.

This red is what it is only by connecting up ... with other reds about it, with which it forms a constellation ... a certain node in the woof of the simultaneous and the successive ... A punctuation in the field of red things, which includes the tiles of roof tops, the flags of gatekeepers ... also a punctuation in the field of red garments, which includes the dresses of women, robes of professors ... ${ }^{2}$

These connections are not a result of an intellectual process of generalising, or the workings of an empirical psychological process of association. They are part of the texture of perceptual experience: "the visible landscape under my eyes is not exterior to ... other moments of time and past, but has them really behind itself in simultaneity ..."3. Such simultaneity of other moments of time within the audible present is also the feature which allows us hear a melody in a piece of music. And the interweaving of the visible and invisible is what we experience when we see the carpet as extending under the cupboard and experience the completion of the pattern. The gestalt of the world is like that of a gesture. It is a movement across time in which a visible or positive presence carries with it an expressive depth.

Also in the Phenomenology he points out that when we perceive each of our senses suggests what is available to others:

\footnotetext{
${ }^{1}$ Merleau-Ponty M., 1968, The Visible and the Invisible, op. cit., p. 215.

2 Ibid., p. 132.

${ }^{3}$ Ibid., p. 267.
} 
We see the rigidity and fragility of the glass, and when, it breaks with a crystal clear sound, this sound is borne by the visible glass. One sees the elasticity of steel, the ductility of molten steel, the hardness of the blade in a plane, the softness of its shavings ... The form of a fold in a fabric of linen or cotton shows us the softness or the dryness of the fibre ... In the movement of the branch from which a bird has just left, we read its flexibility and its elasticity ... we see the weight of a block of cast iron that sinks in the sand ${ }^{1}$.

When I perceive an object, via one sense, a whole range of other possible sensory encounters are implicated, including those involving other senses. And he extends this range of possibilities to include a grasp of possible perceptual encounters which would be had by other perceivers. Our perceptual experience of the world has implicit within it the possibility of what we see being perceived by others, whose experiences of it may be different from ours. The possibility of such differing experiences latent within our own perceptions is part of what makes those perceptions to be of things, of a world. We experience our world as both available to all of our senses and as open to a potentially infinite range of possible modes of perception from different positions within it, perceptions which can never exhaust it. "Every landscape of my life ... is ... pregnant with many other visions besides my own" ${ }^{2}$. The possibilities here are not constituted by multiple acts of imagining consciousness but are implicit in the shape the immediate perceptual world has for us. For Sartre possibilities for our future required acts of negating the world as perceived. For Merleau-Ponty we experience the world as offering possibilities to our bodies. We can make sense of our activities within it by pointing to worldly characteristics in which they are implicit. Merleau-Ponty argues freedom only makes sense within a field of possibilities. Our freedom emerges as a normatively intelligible response, rather than an exercise in transcendence. As a consequence my relation to my past is neither one of its determining the present, nor one in which it provides a ground to be negated. Though not a fate, the past has a weight which bears on my present decisions, and gives "the atmosphere of my present" ${ }^{3}$.

Close reading of the works of both Merleau-Ponty and Sartre allows us to recognise what we have termed the absent present in our perceptual experience of the world, woven into the gestalts of everyday experience. For Sartre the texture of everyday experience was misleading. It disguises from

${ }^{1}$ Ibid., p. 238.

${ }^{2}$ Ibid., p. 123.

${ }^{3}$ Ibid., p. 467. 
us the distinction between the perceived and the imagined, and thereby the extent to which the possibilities we seem to find in the world are of our own making. In contrast, for Merleau-Ponty, the invisible/imaginary texture of the perceived world is something which emerges from our corporeal immersion within it, a manifestation of the multiple possibilities of the real. For Merleau-Ponty, then, if we pay attention to the character of perceptual experience itself, we find the imaginary within it. In this he follows the lead which Kant has provided. Nonetheless he rejects a Kantian metaphysics of transcendental idealism. We need to pay attention to the phenomenology, the world as perceived, without metaphysical speculation as to its source. He dissociates himself from the view of the subject that itself imposes the laws of understanding onto the manifold, in favour of a subject that finds itself able to respond to harmonies encountered in nature. He does away with the transcendent constituting subject, bestowing, via the exercise of spontaneity, form onto a mass of intuitions which have been passively received. Such, he argues, takes us away from the character of the perception itself. To grasp that character we must return to pre-reflective experience:

What have we then at the onset? Not a given manifold with a synthetic apperception which ranges over it and completely penetrates it, but a certain perceptual field against the background of the world ... not a mosaic of qualities, but a total configuration.

'Form' is not privileged in our perception because ... it makes a world possible, (in the Kantian sense), but rather because form is the very appearance of the world not its condition of its possibility (italics mine) ${ }^{1}$.

To perceive is not to experience a multitude of impressions ... it is to see an immanent sense bursting forth from a constellation of givens ${ }^{2}$.

Synthesising activity is not the imposition of conceptual form onto intuited matter. It is rather the taking up or grasping of shape in the world we encounter, and which emerges in relation to our body. The productive imagination here is bodily, and it does not so much impose form as take up form, as a consequence of its sensitivity to the world in which it is placed.

In Merleau-Ponty's later work on institution, Institution and Passivity $^{1}$, he provides an account of the processes whereby the imaginary

${ }^{1}$ Ibid., p. 62.

${ }^{2}$ Ibid., p. 23 
gestalts of our perceived world are initiated, continued and revised. The imaginary as instituted is encountered by us as something which has been deposited: "[the] inter-subjective or symbolic field, [the field of] cultural objects, ... is our milieu., our hinge" ${ }^{2}$. This is an imaginary organisation of existence that is socio-cultural as well as bodily. He writes we need to "Understand the imaginary sphere ... as the true Stiftung [institution] of Being" . Lefort comments that "he uses Stiftung to designate the fecundity deriving from a moment in time ... the workings of culture which opens a tradition" ${ }^{4}$. The distinction between constitution and institution is key here. The imaginary as constituted is dependent on and makes no sense independent of the constituting subject(s). In contrast the instituted imaginary is encountered in the socio historical field. But the instituted imaginary itself depends on a founding moment in which significance is opened, or instituted. He returns time and again to the opening of signification, the creative origin of the imaginary of the world, an originating creative (instituting) moment, in which meaning takes hold, signification becomes actualised. An initiating gesture (an advent) brings into view an aspect of the world, makes it accessible to ourselves and others. A gesture that is something to be continu$e d$ in a way that is open, rather than determined, the invitation to a future. Lefort comments; "if institution is openness to, openness is always produced - on the basis of" . We find "a certain variation in the field of existence

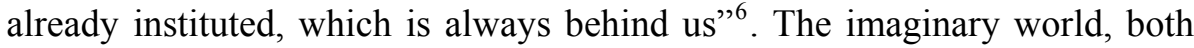
material and social, which we encounter "sedimented in me a meaning as the invitation to a sequel, the necessity of a future" ${ }^{7}$. What Merleau-Ponty emphasizes is the openness of such sequels. Even though each is grounded, he insists on the dimension of difference in the way in which different subjects/times may form a sequel, further institutions which are "echoes and exchanges" 8 of each other and that which they follow. And on the basis of which themselves new instituting events (advents) will take place. The advent of new imaginaries, emerges, then, from the encounters of bodies and world, and previously instituted imaginaries.

\footnotetext{
${ }^{1}$ Merleau-Ponty M., 2010, Institution and Passivity, transl. by Lawlor and Massey, with a forward by Claude Lefort, Northwestern University Press Evanston Illinois.

${ }^{2}$ Merleau-Ponty M., 2010, Institution and Passivity, op. cit., p. 6.

3 Merleau-Ponty Maurice, 1968, The Visible and the Invisible, op. cit., p. 258.

${ }^{4}$ Lefort C. forward to Merleau-Ponty M., Institution and Passivity, op. cit., p. xv.

${ }^{5}$ Ibid., p. xi.

${ }^{6}$ Merleau-Ponty M., 2010, Institution and Passivity, op. cit., p. 49-50.

${ }^{7}$ Ibidem.

${ }^{8}$ Merleau-Ponty M., 2010, Institution and Passivity, op. cit., p. 15.
} 


\section{The Affective-Cognitive Synthesis}

The final strand which I want to briefly highlight in articulating the responses of Sartre and Merleau-Ponty to Kants' writings on the imagination concerns the intimate relation between imagination and affect. The notion of affect has two aspects. One is the capacity of our bodies to be affected, to bear the marks of our interactions with the world and other bodies. Another is our capacities to respond, expressively or purposively. Both receptivity and spontaneity are in play. Both Sartre and Merleau-Ponty articulated the way in which the imaginary offers possibilities for response, the imaginary thereby carrying affective salience. (Although not discussed here we find parallels in the writings of Castoriadis on the radical imagination, stressing the interweaving of the affective and the cognitive in its workings, and this was also found much earlier in Spinoza).

In the section "Affectivity", in Sartre's text The Imaginary, he characterises the "affective-cognitive synthesis" which is "the deep structure of image consciousness" 1 . In these discussions he rejects an account of feeling/affect as a "purely subjective and ineffable shiver" linked externally (causally) and contingently with representations. In its place he offers a "living synthesis". To hate Paul is not just for Paul to be the object of an intellectual judgment, it is to be conscious of Paul as hateful, and this is to make a certain sense of Paul, to experience him as appearing to me with a certain "affective structure" . If I love "the long fine white hands" of someone "this love ... could be considered as one of the ways that they have appeared to my consciousness". But this is not a cognitive sense but an affective one: "the affective form entirely permeating the object" 3 . He quotes a passage of D.H. Lawrence: "It was always the one man who spoke. He was very young, with quick large, bright dark eyes that glanced sideways at her ... His long black hair, full of life, hung unrestrained on his shoulders". Sartre comments: "Lawrence excels at suggesting, while he seems only to be describing, the form and colour of objects, those subdued affective structures that constitute their deepest reality" ${ }^{\text {. }}$.

These affective structures are, for Sartre, the work of imaging consciousness. Desire is provided with an imaginary object which tells us what the desire is a desire for: "desire and disgust exist at first in a diffuse

\footnotetext{
${ }_{1}^{1}$ Sartre J.P., 2004, The Imaginary, op. cit., p. 73.

${ }^{2}$ Ibid., p. 69

${ }^{3}$ Ibidem

${ }^{4}$ Ibid., p. 69-70.
} 
state ... in being organized ... into an imaging form, the desire is made precise and concentrated"1. I awake restless. It is not clear whether the physiological discomfort is hunger or sexual desire. The matter is settled by the direction which my imagining consciousness takes. To experience the desirability of the hands is to surpass (sometimes unaware) their physiological form and constitute them into an image of desirability, giving the hands to me in their affective form. It is only by means of these affective forms (images) that we can become aware of our desires, whose intentional objects are the posited images of imaging consciousness. "The image is a kind of ideal for the feeling" 2 . My love for Annie consists, in part, by my making her "irreal face" 3 appear when she is absent, and, crucially, by the form it takes for me when it appears. However, even when Annie is present, her attribute of being lovable is an imagined one. These affective qualities for Sartre enter phenomenologically into the experience of the perceived object, and cannot be detached by the unreflecting consciousness. Faced with such qualities I react: "this book for example $\ldots$ is entirely suffused by ... affectivity ... faced with this book I do not remain inactive ... I pick it up or put it down, I do not like its binding, I make judgments of fact and value" ${ }^{4}$. And these responses register the affective qualities it holds for me. For Sartre, then, image and affect are internally related: "if the image of a dead one appears to me suddenly ... the ache in my heart is part of the image" 5

Merleau-Ponty, along with Sartre, views the imaginary as providing us with the affective depth of the experienced world. "Quality, light, colour, depth, which are there before us, are there only because they awaken an echo in our bodies and because the body welcomes them" " "Things ... arouse in me a carnal formula of their presence" ${ }^{\text {. }}$. This carnal formula is the manifestation of the affective shape of the world. The imaginary shape the world takes for us is therefore constitutively tied up with ways of responding to and acting in relation to it and it this is what we mean by claiming that it has affective texture. Merleau-Ponty draws attention to the fact that once we experience the world as having a certain shape we already have a world which carries affective content. "We must no longer ask why we have

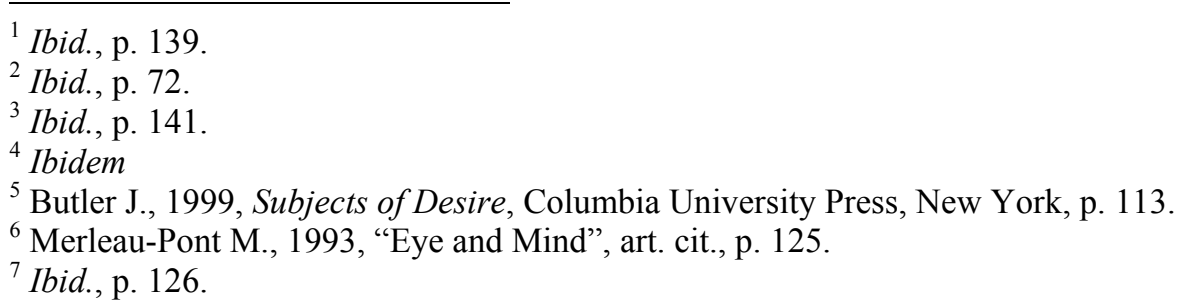


affections in addition to 'representative sensations' since the representative sensation also ... is affection, being a presence to the world through the body and to the body through the world"1. It is through the images in terms of which we perceive the world that the world makes "affective sense" to us. We experience it as a world of possibilities for us, both for intentional projects and expressive responses.

\section{Summary}

This paper has outlined what Merleau-Ponty coins "the imaginary texture of the real" , the imagination at work in the everyday world which we perceive, the world as it is for us. The imaginary on this account is not the realm of fantasy and negation. When it is manifest in perception, it is the animating form of perceived experience, weaving together the present and the elsewhere into a Gestalt, which we find in the world as experienced by us. This gestalt I have suggested, following Kant and Merleau-Ponty, is neither imposed nor simply discovered, but emerges from a creative interplay between corporeal subjects and the world (including the social world) within which they are placed, and to which they are sensible. The gestalt interweaves the manifold of the present and the elsewhere, the visible and what is in the visible giving immediate perception an experienced depth and also, an affective character, a salience and significance, which the imaginary texture carries. As phenomenological writers have made clear, the world is experienced by us as enticing, that is it is experienced by means of cognitive and affective images. That imaginary world, as described here, is our most direct and immediate mode of perception.

\section{References}

Brann E. T. H., The World of the Imagination, Rowman \& Littlefield, 1991.

Butler J., Subjects of Desire, Columbia University Press, New York, 1999.

Cohen T., and Guyer P., Intrroduction to Essays in Kant's Aesthetics, University of Chicago Press, Chicago, 1982.

Guyer Paul, "Kant Immanuel (1724-1804)", Routledge Encyclopedia of Philosophy online, 2004.

\footnotetext{
${ }^{1}$ Merleau-Pont M., 1968, The Visible and the Invisible, op. cit., p. 239.

${ }^{2}$ Merleau-Pont M., 1993, "Eye and Mind", art. cit., p. 126.
} 
Hughes F., Kant's Aesthetic Epistemology, Edinburgh University Press, Edinburgh, 2007.

Husserl E., Logical Investigations vol 2 bk 6, trans J. Findlay, New York, Humanities Press, 1970.

Husserl E., Ideas; General Introduction to Pure Phenomenology, trans. W. Gibson, Collier, New York, 1962.

Kant I. [1781/1787], Critique of Pure Reason, transl. N. Kemp Smith, London, McMillan, 1929.

Kant I. [1790], Critique of Judgement, trans. J.C. Meredith, Oxford University Press, Oxford, 2007.

Merleau-Ponty M., The Visible and the Invisible, ed, C. Lefort, trans. A. Lingis, Northwestern University Press, Evanston, 1968.

Merleau-Ponty M., "Eye and Mind" in Galen A. Johnson (ed.), The Merleau-Ponty Aesthetics Reader, Northwestern University Press, Evanston, Illinois, 1993.

Merleau-Ponty M., Institution and Passivity, transl. by Lawlor and Massey, with a forward by Claude Lefort, Northwestern University Press Evanston Illinois, 2010.

Sartre J.P., The Imaginary, A Phenomenological Psychology of the Imagination, trans. J. Webber, Routledge, London, 2004.

Sartre J.P., Imagination, transl. K. Williford and D. Rudrauf, New York, Routledge, 2012.

Schaper E., "Taste, sublimity and genius: The aesthetics of nature and art", in P. Guyer (ed.), The Cambridge Companion to Kant, Cambridge University Press, Cambridge, 1992.

Strawson P., "Imagination and Perception", in P. Strawson, Freedom and Resentment, Methuen, London, 1974.

Young J. M., “Kant's View of Imagination”, Kant Studien, vol. 79, 1988, pp. 140164. 